\title{
SCENES OF LAPWING-BIRD IN THE ANCIENT EGYPTIAN TOMBS
}

\author{
By \\ Radwa Mohamed Aly Shelaih \\ Lecturer of Tourism Guidance \\ Faculty of Tourism \&Hotels-Suez Canal University
}

مجلة كلية السياحة والفنادق ملحق العدد الأول يونيو 2017 العالعيات

الخاص بالمؤتمر العلمي الأول السياحة و الاثار - الفرص و التحول التحديات 


\title{
SCENES OF LAPWING-BIRD IN THE ANCIENT EgYPTIAN TOMBS
}

\section{Abstract:}

\author{
Radwa Mohamed Aly Shelaih ${ }^{1}$
}

The migration of birds to northern Africa during the winter is quite common in the Nile Delta. The arrival of these birds in the Egyptian skies fascinated the ancient Egyptians who include these species in the scenes decorating the walls of the temples and the tombs. Considering the fishing, clap netting and fowling scenes in the papyrus thickets in ancient Egypt, so many birds were depicted in these scenes such as: Hoopoe, purple Gallinule, Cormorant, Golden Oriole and Lapwing. These birds are shown in a very symmetrical manner. Rather than flying in various directions, they are arranged flying to the left and the right. Among these species the research focuses on the lapwing bird and its representation in the ancient Egyptian tombs, as most of scholars concentrated only on studying the religious symbol of the Lapwing and it's relation with the royalty. The research aims to study the various scenes of the Lapwing bird in the ancient Egyptian tombs, to illuminate the characteristic behaviors of the Lapwing bird in these scenes and to understand the purpose from depicting the Lapwing bird in the ancient Egyptian burial tombs.

\section{Introduction:}

Ancient Egyptians applied the birds' ability to travel between worlds to their conception of death and men's fate after being buried in their tombs2. Migratory birds also occupied an important place in ancient Egyptian symbolism3. The inhabitants of the Nile Valley were aware of the semiannual journey of several species of birds and differentiated them from the local birds by giving them specific names gS or xtyw-tA4. Their regular arrival twice a year may symbolize to the hope of new life after death5. The migratory birds became symbols of conquest of death6. In addition to giving ancient Egyptians hope for rebirth and afterlife, birds were also significant during their lifetime7. As the Lapwings which were depicted with raised arms in praise before the living Horus embodied by the king ${ }^{8}$.

\section{Description of the Lapwing}

The lapwings are species of crested plovers. The northern lapwing is one of these species which has been abundantly represented in both Egyptian art and hieroglyphs9. It is a well-known wader bird of the plover family, common in the temperate parts of the Old World10. It is a $28-33 \mathrm{~cm}$ 
long bird with a $67-87 \mathrm{~cm}$ wing span11. It can be identified by its rounded wings, short pointed bill, rounded head, long squared tail and especially by the long crest on its head12. It is also the shortest-legged of the lapwings. Its color is mainly black and white, but the upper plumage is dark metallic alternating green and purple, under plumage is white, it has a black chest and Orange under the tail13. The lapwing has a black beak, brown legs and dark brown eyes. The male has along crest and a black head, neck and chest with a white face (fig.1). Females and young birds have shorter crests, and have less marked heads, but plumage is quiet similar14 (fig.2).

\section{Distribution:}

The lapwing breeds in parts of Europe, northern Asia, the Middle East and Morocco. It migrates in parts of Europe, southern Asia, the Middle East and North Africa during the winter. In Modern Egypt the lapwing is a winter visitor in the Nile Valley and Delta, the Faiyum, along the Mediterranean Sea coast, West of Alexandria, in the vicinity of the Suez Canal, and the Dakhla and Siwa Oasis. The lapwing inhabits open mudflats and lays its eggs on nests made of reeds and marshland plants in damp ground15. It eats small invertebrates picked out of the mud or soil ${ }^{16}$.

\section{Etymology of the Name}

The bird is called in English "lapwing", or "pewit" (imitative of its cry), or "green plover" (emphasizing the color of the plumage) ${ }^{17}$.

18 "أبو طيط"، أو "الزقزاق الأخضر"، أو "رسول الغيث" In Arabic it is called . The scientific name of the northern lapwing is (Vanellus Vanellus) or (Vanellus Cristatus), which is Latin and derives from vannus a winnowing fan19.

The name Lapwing derived from an Old English word "to leap" connected with "wink" meaning "to totter" or "waver". The spelling was changed in Middle English by association with "lap" and "wing"20. The bird was named from the manner of its flight upwards, downwards, and in circles 21 . It has been variously attributed to the "lapping" sound its wings make in flight, due to its large wings ${ }^{22}$.

\section{Lapwing- Bird in Ancient Egypt}

The lapwing is one of the earliest birds in Egyptian art being depicted both in hieroglyphs and reliefs from Pre-dynastic period23 through to the Roman Period24.

The ancient Egyptian name of the bird is unknown but the ancient Egyptians referred to as rhyt which presumed to be the name of the bird and 
used as a sign for rhyt

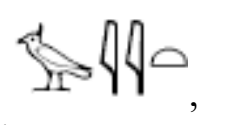

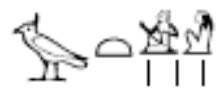
"mankind" or "subject people" 25.

"common people",

The lapwing-bird was also the symbol of rule of Upper Egyptian king over Lower Egyptian people due to its habit of wintering in the Delta26.

\section{Lapwing in Inscriptions}
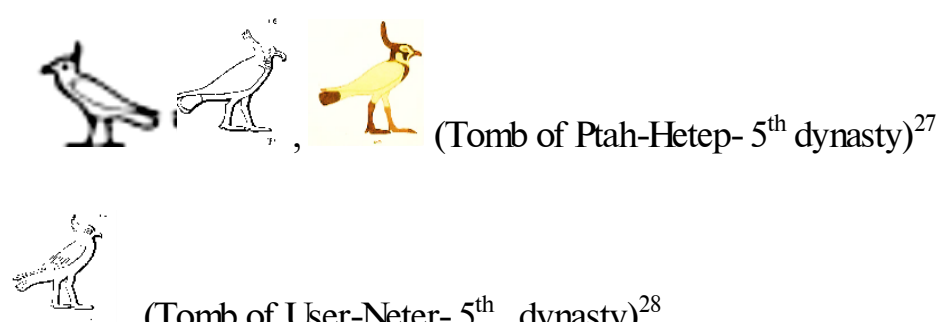

(Tomb of User-Neter- $5^{\text {th }}$ dynasty $)^{28}$

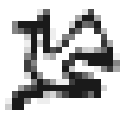

Lapwing with wings twisted round one another $(\mathrm{G} 24)^{29}$.

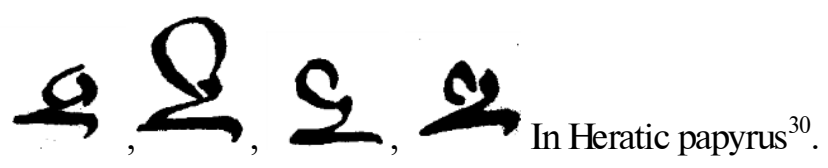

$\lambda \mathbf{l}$

In Coptic $^{31}$.

In Old kingdom hieroglyphs

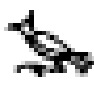

is sometimes found in place of

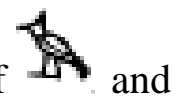

later is of common occurrence32. On this appearance there is an interesting comment that live ducks and other birds are frequently to be seen in the modern Egyptian markets with their wings twisted one around the other to prevent them from flying and walking33.

\section{Scenes of the Lapwing in the Tombs:}

\section{Tombs of the Old Kingdom}

The depictions of daily life activities surviving on the walls of the private tombs testify to the continued interest of ancient Egyptians in these feathered visitors. As the Egyptian artists talented in observing nature, their love of detail in their art, have created the most magnificent images of birds. A scene from the tomb of Niankhkhnum and Khnumhotep at Saqqara dates 
back to the 5th dynasty represents the deceased in a fowling scene and in front of him is an area above the papyrus plant alive with numerous birds distributed from their nests and safe hiding places among the stalks by hunters34. Among these birds is the lapwing characterized by its long crest above the head, depicted with its wings outstretched forward and the feet are rendered when flying, as the artist tried to show the movement of the bird in flying (fig.3) 35 .

One of the charming scenes is from the tomb of Nefer at Saqqara, which dates back to the 5th dynasty, it represents the daughter of the owner of the tomb facing toward the right viewing the activities of fowlers, and her left arm is raised holding a lotus blossom up to her nose. In her right hand, she clutches a lapwing by its wings. The plover was in all probability the girl's pet or plaything. Lapwing was rarely kept as pets in ancient Egypt (fig.4)36.

Another scene from the tomb of Ptahhetep and Ankhethetep at Saqqara dates to the end of the 5th dynasty and the beginning of the 6th dynasty, birds are represented above the papyrus thicket flying in different directions, they are in three rows, among these birds in the upper row is the lapwing flying to the right with outstretched wings, and in the lower row is another lapwing bird flying to the left (fig.5)37.

A scene from tomb of Hesi at Saqqara dates back to the 6th dynasty, it represents several rows of papyrus blossoms form horizontal border across the scene, birds are shown above the thicket in a symmetrical manner, arranged in two rows in the upper row at the beginning is a lapwing flying to the right, with outstretched wings and a butterfly is shown infront of it. Another lapwing is depicted on the lower row typical to the previous one in the upper row, but it is flying to the left (fig.6)38.

Another scene from the tomb of Hesi similar to the previous one but the lapwing appears here in a different pose with its wings outstretched above the back (fig.7)39.

In addition to visits made to the marshes for hunting or "sightseeing," these journeys also possess religious or ritual significance, as the journey for the purpose of pulling papyrus for Hathor40. This ritual scene appears here in the tomb of Iasen, located on the Giza plateau, in what is called the Western Cemetery; it dates back to the 6th dynasty, representing him performing the activity of sSS WAD ("pulling papyrus") and throwing a stem of papyrus, which he pulled from those around him. The setting is provided by a background of massive, serried papyrus stems rising far 
above the water. Their umbels provide a home for thronging birds, insects, and attacking carnivores41. The lapwing bird characterized by its crest is perching towards the right side above one of these umbels (fi9.8) 42 .

One of the most impressing scenes takes place in a papyrus thicket from the tomb of Nikauisesi, at Saqqara, Room I, east wall, it represents on the right side a lapwing chick hooping on a papyrus stem, as the artist tried to show the behavior of the bird which is looking frightened from the scene of attacking a genet to a nest infront of it (fig.9)43.

Tombs of the Middle Kingdom

Using ancient colors as means of identification helped to show that two species have been used to depict the rekhyt-bird44. There is another type of crested lapwing which occurs in Northern Africa but no longer in Egypt named the black-headed plover (Vanellus tectus)45. A perfect representation of the bird can be seen in the top register of the south wall of the tomb of Baqet III at beni Hassan46 (fig.10).

\section{Tombs of the New Kingdom}

A scene from the tomb of Amenemhet (No.82), at Thebes, it dates back to the 18th dynasty, it represents a lapwing with outstretched wings flying above a papyrus thicket (fig.11) 47 .

\section{Tombs of the late period}

A lapwing appears in a lime stone relief from the Theban tomb of Prince Mentuemhat which dates back to the 25th dynasty, and now in the Cleveland museum, resting among the stems and umbels of the papyrus thickets. It appears to be a female lapwing due to its short crest (fig.12)48.

\section{Conclusion}

Birds' fascinated Egyptian artists and scribes, they observed the birds' characteristic behaviors, which became, in their imagination, representative of human reactions. The sociable behavior of the northern lapwing (Vanellus Vanellus) in the swamps, their mournful cry and energetic wing flapping during the breeding season, their nervous defensive behavior when under attack, came to symbolize the subordination of common people to the Pharaohs.

The lapwing was a stock item of scenes displaying a papyrus swamp especially in the Old kingdom tombs more than in later tombs.

Through the previous scenes the lapwing has never shown captured in the clap-net as it symbolize to the common people.

It appears to be used as children's pet in ancient Egypt (fig.4). 
The artist shows the lapwing's different behaviors in flying, roosting and hooping when frightened of attacking.

The difference between the male and female adult lapwing and the chick lapwing appears in some scenes as in figs (3\&9).

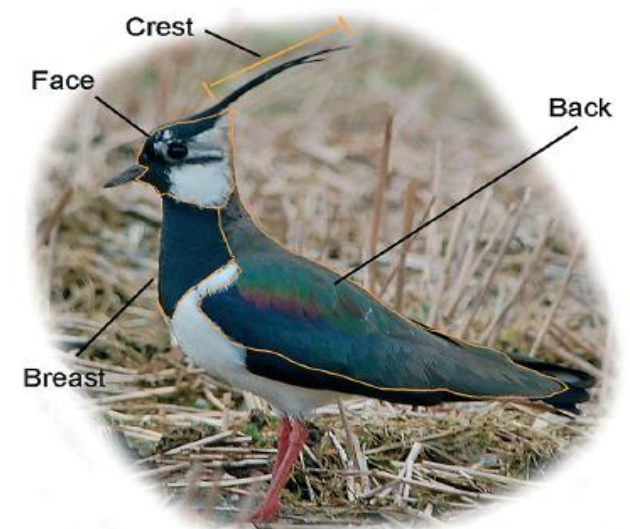

Fig.1 male northern lapwing

Schonert.B, et al "Plumage Ornaments in Male Northern Lapwings Vanellus Vanellus": in Ornis Fennica 91, Bergen-Norway, 2013, p.81. www.ornisfennica.org/pdf/latest/3Schonert.pdf

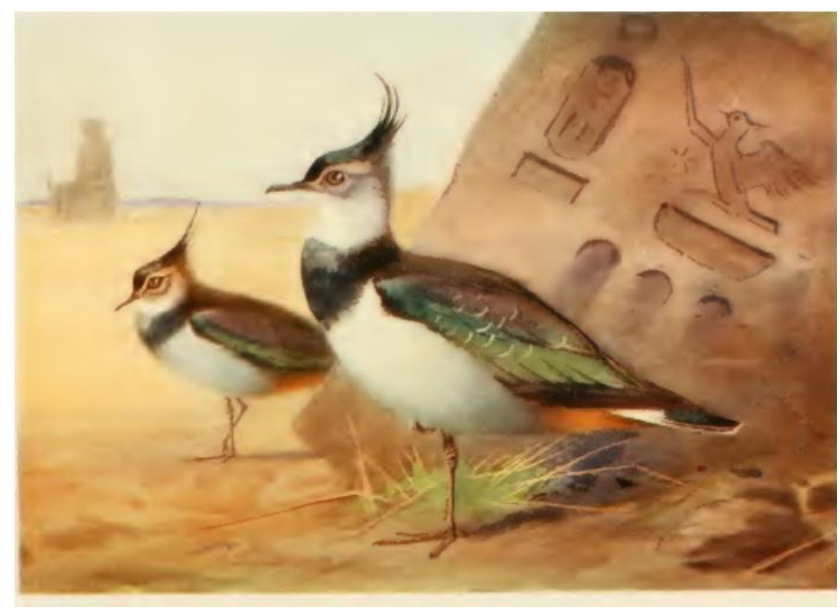

Fig.2 female northern lapwing

Whimper, C., Egyptian Birds For The Most Part Seen in the Nile Valley, London, 1909, pp.11-112. 

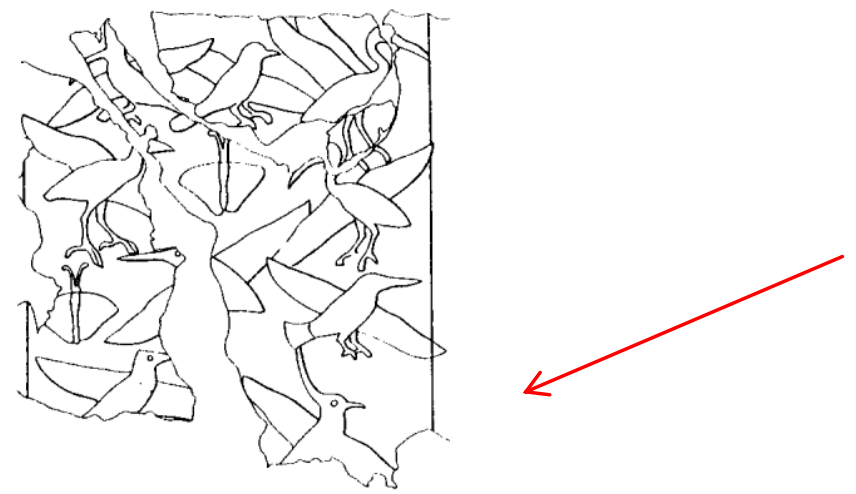

Fig.3 Tomb of Niankhamun, flying lapwin, south wall of the portico, lower register, right side.

M.Moussa.A., Altenmuller.H., Das Grab des Nianchnum und Chnumhotep, Mainz, 1977, abb.6.

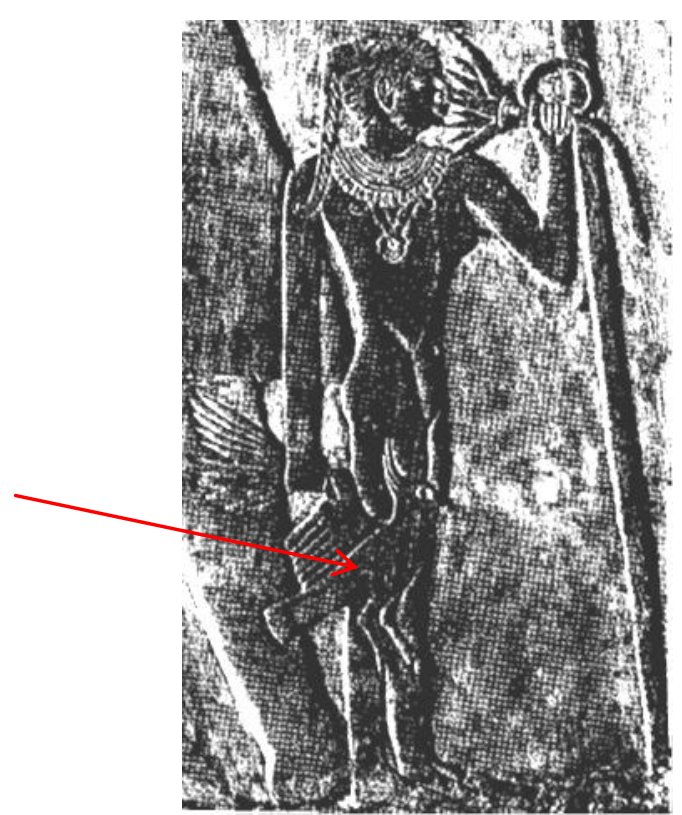

Fig.4 A relief of young girl clutches a lapwing from the tomb of Nefer at Saqqara, $5^{\text {th }}$ dynasty.

F.Houlihan.Patrick, Op.cit, p.96, fig.132. 


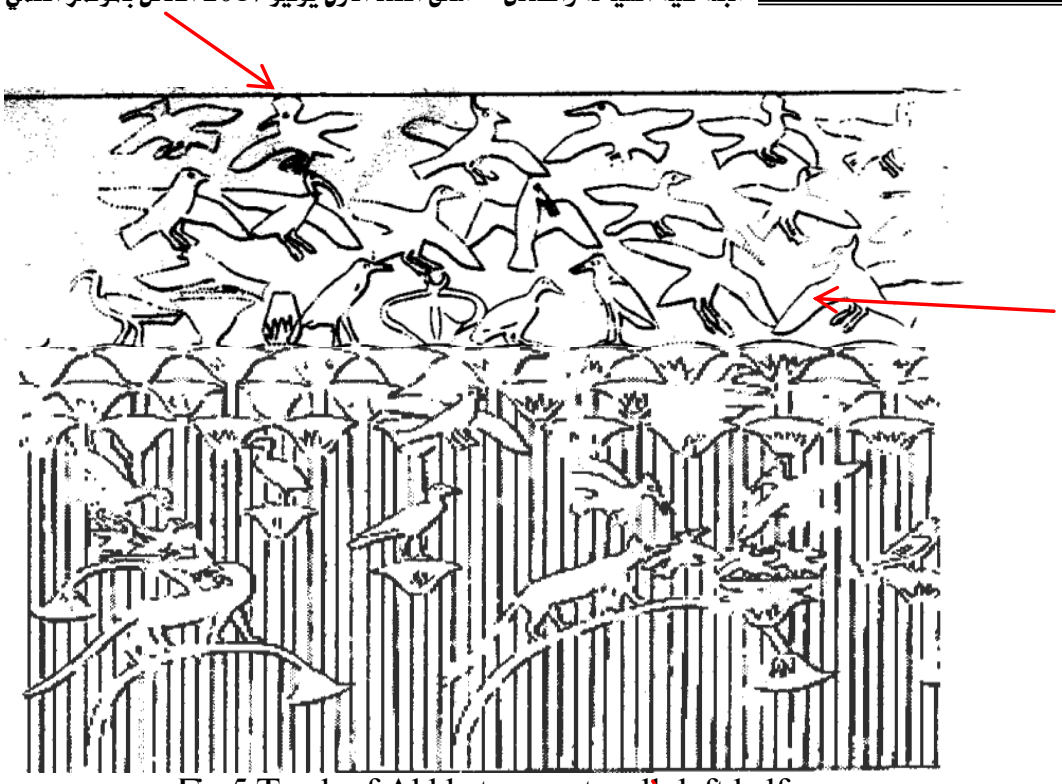

Fig.5 Tomb of Akhhetep, east wall left half.

Davies, G., The Mastaba of Ptahhetep and Akhethetep at Saqqareh, Part II, London, 1901, pl.xiii.

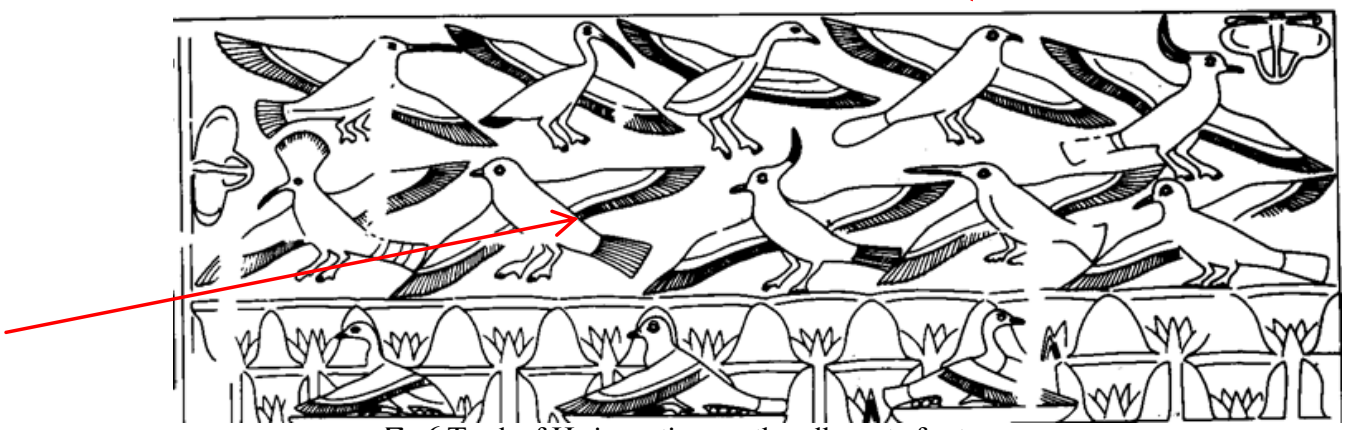

Fig.6 Tomb of Hesi , portico, south wall, east of entrance

Kanawati, N., Abder-Raziq, M., The Teti Cemetery at Saqqara, vol.5, the Tomb of Hesi, ACE: Report13, 1999,

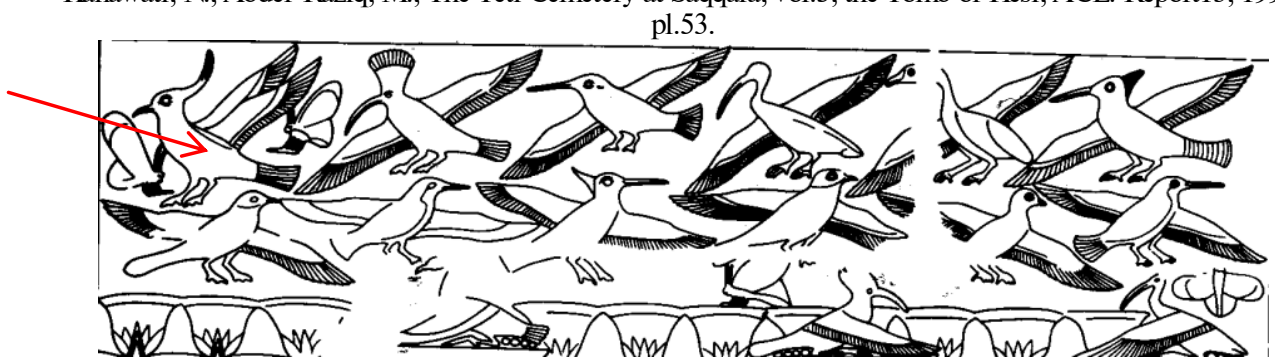

Fig.7, Tomb of Hesi , portico, south wall, west entrance

Ibid, Pl.54. 


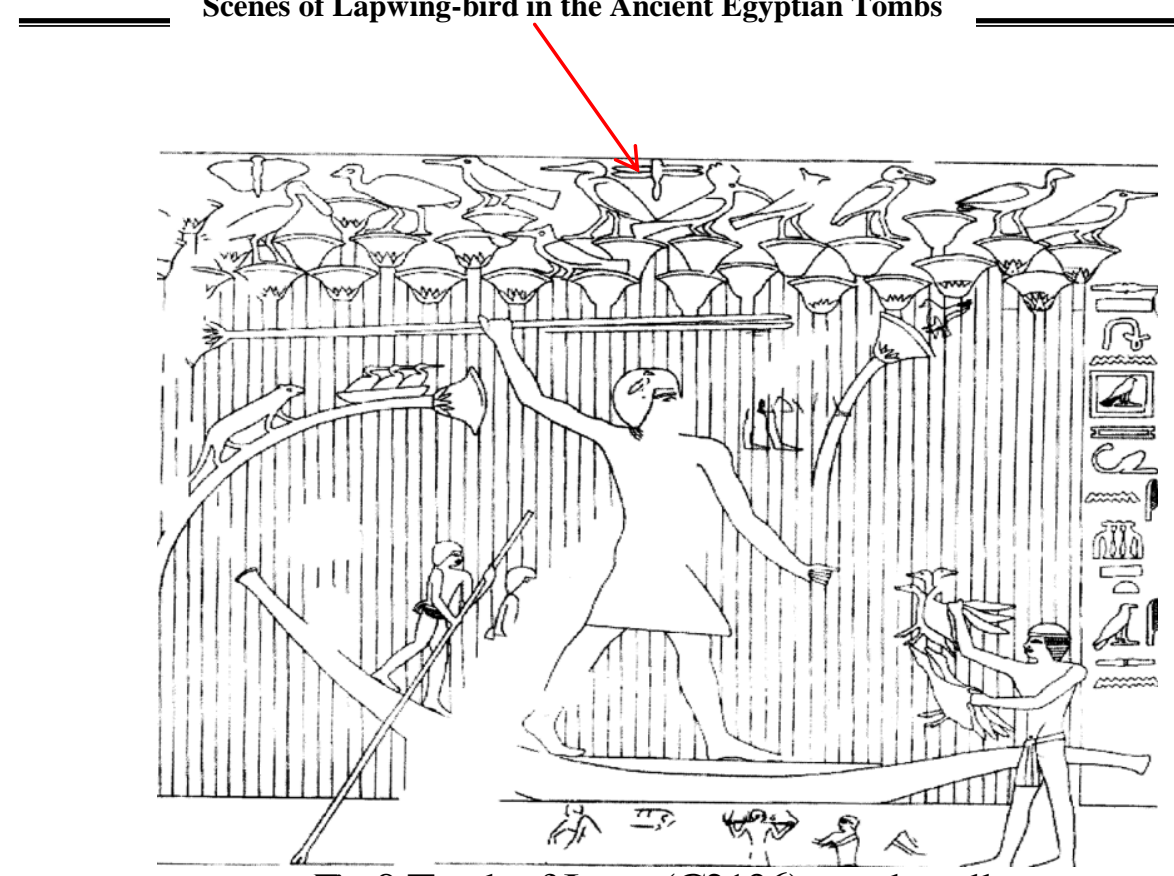

Fig.8 Tomb of Iasen (G2196), north wall.

Simpson, W.K., Mastabas of the Western Cemetery, Part I, Museum of Fine Arts, Boston, 1980, fig.30.

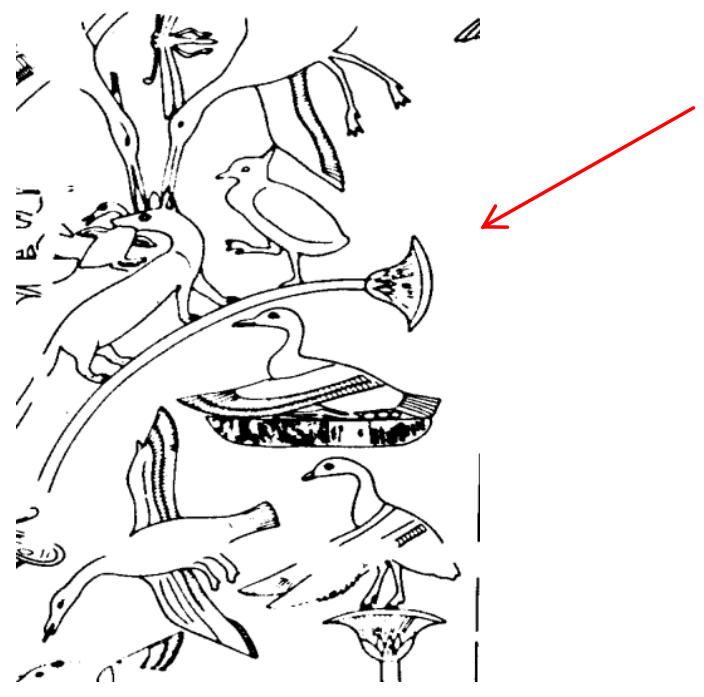

Fig.9 A lapwing chick, Tomb of Nikauisesi, Room I, east wall.

Kanawati.N, Abder-Raziq, The Teti Cemetery at Saqqara, Vol.VI, the Tomb of Nikauisesi, England, 2000, pl.50. 


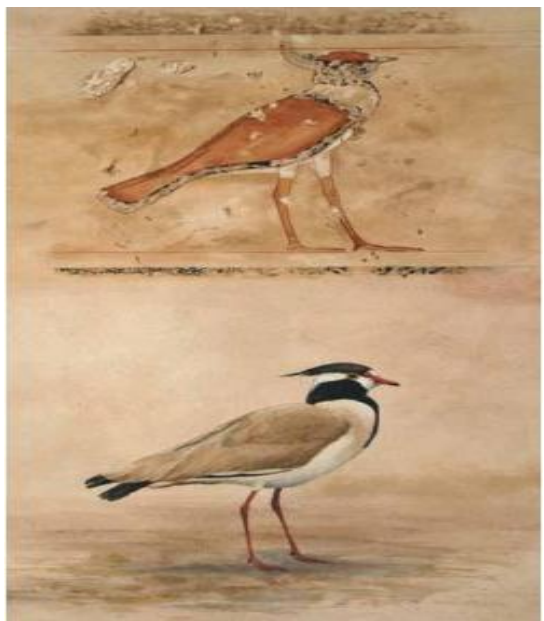

Fig.10 A Comparison of the lapwing bird from the tomb of Baqet III at beni Hassan With a live Black-headed plover (Vanellus tectus).

Bailleul- Leusuer., Rozenn, Op.cit, fig 9.11.

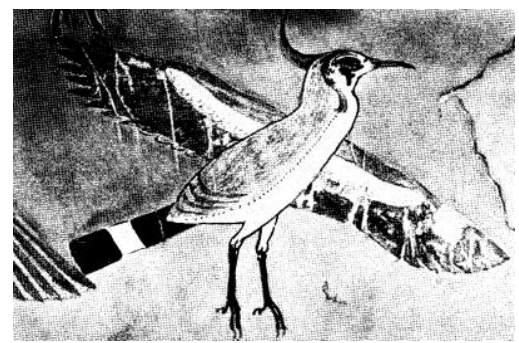

Fig.11 a flight lapwing from the tomb of Amnemhet, $18^{\text {th }}$ dynasty.

F.Houlihan.Patrick, Op.cit, fig.137.

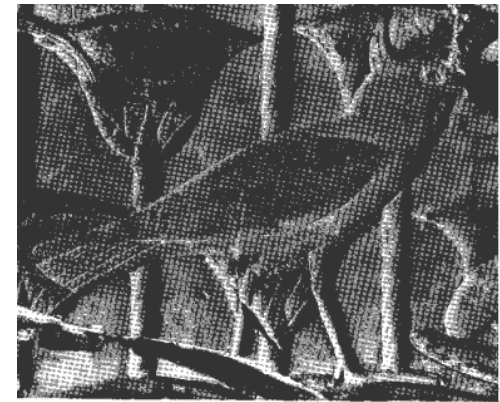

Fig.12 A lapwing in a lime stone relief from the Theban tomb of Prince

Mentuemhat, $25^{\text {th }}$ dynasty.

F.Houlihan.Patrick, Op.cit, fig.137. 
${ }^{1}$ Lecturer of Tourism Guidance Faculty of Tourism \&Hotels-Suez Canal University

2 Bailleul- Leusuer., Rozenn, Between Heaven and Earth, Birds in Ancient Egypt, Chicago, 2012, p.16.

3 Ibid, p.16.

4 Ibid, p.16.

5 Hornung, E. \& E. Staehelin, Skarabäen und andere Siegelamulette aus Basler Sammlungen, Mainz, 1976, p.135

6 Ibid, p.136.

7 Bailleul- Leusuer., Rozenn, Op.cit, p.16.

8 Ibid, p.16.

9 F.Houlihan.Patrick, The birds of Ancient Egypt, England, 1986, p.93; Griffin, K., "Images of the Rekhyt from Ancient Egypt" in: Ancient Egypt magazine, vol.7, No.2 Issue 38,2006, p.45.

10 The Compact Edition of the Oxford English Dictionary, Vol.1, London, 1971, p.1570;

قاموس أطلس الموسوعى إنجليزى-عربى، جمهورية مصر العربية، الطبعة الثالثة، 2003، ص.712.

11 M.Perrins.Christopher, Op.cit, p.140, no.5.

12 F.Houlihan.Patrick, Op.cit, p.93.

13 Whimper., C., Egyptian Birds For The Most Part Seen In The Nile Valley, London, 1909 , pp.11.

14 https://en.wikipedia.org/wiki/Northern_lapwing

15 Nibbi.Alessandra, "Some remarks on two very early but enduring symbols in ancient Egypt", in: Late Prehistory of the Nile Basin and the Sahara, Poznan, 1989, p.341.

16 The New Oxford Illustrated Dictionary, Op.cit, p.953.

17 The New Oxford Illustrated Dictionary, Vol.1, Oxford University press, 1978, p.953.

18 Brunn.bertel, Baha el Din.Sherif, Common Birds of Egypt, 3rd edition, Cairo, 1996, p.28, pl.7;

$$
\text { قاموس أطلس الموسوعى إنجليزى-عربى، ص. }
$$

19 Jobling, James. A., The Helm Dictionary of Scientific Bird Names, London, 2010, p. 397.

20 The Compact Edition of the Oxford English Dictionary, Op.cit, p.1570; Pearsall.Judy, The New Oxford Dictionnary of English, New York 2001, p.1037.

21 M.Perrins.Christopher, The Illustrated Encyclopedia of Birds, The Definitive Guide to Birds of the World, Translated into Arabic By Yaziji.Adnan, London, 1990, p.140, no.5.

22 M.Perrins.Christopher, Op.cit, p.140.

23 See,for instance, the top register on the fragmentary mace-head of king Scorpion, now in the Ashmolean Museum: Griffin, K., Op.cit, p.46; Nibbi.Alessandra, Op.cit, p.340 (fig.2).

24 See, for instance, a frieze of rekhyt birds in the Temple of Deir el-Haggar- Dakhla Oasis: Griffin, K., Op.cit, p.49.

25 Dickson, Paul, Dictionary of Middle Egyptian in Gardiner classification order, Francisco, California, USA, 2006, pp.78-79; Shaw, I., Ancient Egypt A Very Short Introduction, Oxford, 2004, (Glossary) .

26 Nibbi.Alessandra, Op.cit, p.341. 
27 Gardiner, A., Egyptian Grammar, 3rd edition, Oxford, 1976, p.470 (G 24); Davies, N de G., The Mastaba of Ptahhetep and Akhethetep at Saqqareh, Part I, London , 1900, p.20 fig.84; 410; Wb, II, p.447. (8, 10); Dumas, F., Valeurs phonétiques des signes hiéroglyphiques d'époque gréco-romaine, Montpellier, 1988, p.326 (665, 675).

28 Murray, A.M., Saqqara Mastabas, Part I, London, 1905, p.41, pl.XXXVII.

29 Gardiner. Alan., Egyptian Grammar, 3rd edition, Oxford, 1976, p.470 (G 24).

30 Möller G., Hieratische Paläographie II, Leipzig, 1909, 200-209 (201).

31 AEO.i, $102 *$.

32 Ibid, 102*.

33 Ibid, 101*.

34 Donovan.L\& McCorquodale, K., Egyptian Art Principles and Themes in Wall Scenes, 1st edition, Egypt, 2000, p.114.

35 M.Moussa.A., Altenmuller.H., Das Grab des Nianchnum und Chnumhotep, Mainz, 1977, abb.

36 F.Houlihan.Patrick, Op.cit, p.94, fig.132.

37 Davies, G., The Mastaba of Ptahhetep and Akhethetep at Saqqareh, Part II, London, 1901, pl.xiii.

38 Kanawati, N., Abder-Raziq, M., The Teti Cemetery at Saqqara, vol.5, the Tomb of Hesi, ACE: Report13, 1999, pl.53

39 Ibid, pl.54.

40 Kantor.H.J., Plant Ornament in the Ancient Near East, Chapter II: The Swamp Plants Oriental Institute, University of Chicago, 1999, p.8-9. https://oi.uchicago.edu/pdf/HJKII.pdf

41 Kantor.H.J., Op.cit, p.8-9.

42 Simpson, W.K., Mastabas of the Western Cemetery, Part I, Museum of Fine Arts, Boston, 1980, fig.30.

43 Kanawati.N, Abder-Raziq, The Teti Cemetery at Saqqara, Vol.VI, the Tomb of Nikauisesi, England, 2000, pl.50.

44 Bailleul- Leusuer., Rozenn, Op.cit, p.86.

45 Ibid, p.87.

46 Ibid, p.88, fig.9.11.

47 F.Houlihan.Patrick, Op.cit, p.96, fig.137.

48 F.Houlihan.Patrick, Op.cit, p.96, fig.136; The Bulletin of the Cleveland Museum of Art, 1965, p.104, fig.3. 